\title{
Development and Comparison of Conventional PCR and SYBR Green Real Time PCR for Detection of Aggregatibacter actinomycetemcomitans and Tannerella forsythensis
}

\author{
Mohammad Soleimani ${ }^{1, *}$, Mohammad Reza Zolfaghari ${ }^{1}$, Abbas Morovvati ${ }^{1}$ \\ ${ }^{1}$ Department of Microbiology, Qom Branch, Islamic Azad University, Qom, IR Iran \\ *Corresponding author: Mohammad Soleimani, Department of Microbiology, Qom Branch, Islamic Azad University, Qom, IR Iran, P.O. Box: 37185/364. Tel:+98-2517780001, Fax: +98- \\ 2517780001, E-mail: soleimanidor@yahoo.com. \\ Received: June 13, 2012; Revised: August 25, 2012; Accepted: October 2, 2012
}

\begin{abstract}
Background: Aggregatibacter actinomycetemcomitans and Tannerella forsythensis are two major pathogens in destructive periodontal disease in humans. The detection of these bacteria is needed for diagnosis and management of the mentioned diseases.

Objectives: We aimed to develop and compare improved multiplex conventional and SYBR green real time PCR assays for a specific diagnosis of the organisms based on specific marker genes.

Materials and Methods: Both PCR approaches were performed with primers targeting diagnostic genes of the organisms, $h b p A$ gene of A. actinomycetemcomitans and $16 \mathrm{~S}$ rRNA gene of $T$. forsythensis. For preparation of a stable positive control, the PCR products were cloned into pTZ57R/T plasmid. The test specificity was evaluated using the same PCR reactions but in the presence of genomes of various negative control bacteria.

Results: As expected, agarose gel electrophoresis of PCR products of the hbpA and 16S rRNA genes showed 160 bp and $250 \mathrm{bp}$ bands respectively. Temperature melting analyses of the SYBR green real time PCR assays showed the $\mathrm{Tm}$ at $78.02{ }^{\circ} \mathrm{C}$ and $84.62{ }^{\circ} \mathrm{C}$ for $\mathrm{hbpA}$ and $16 \mathrm{~S}$ rRNA genes respectively. The amplification results using negative control genomes as template was negative showing the specificity of both designed assays. The detection limits of the conventional PCR assay for hbpA and 16S rRNA genes were 5200 and 1200 copies of each gene, respectively. The designed SYBR green PCR assays tenfold increased the test sensitivity.

Conclusions: The designed assays provide simple, reliable, and rapid procedures that identify two main periodontal pathogens. Theses assays are new diagnostic opportunities in our laboratory and also are working as important supplements of the current time consuming phenotypic assays.
\end{abstract}

Keywords: Periodontitis; Real-Time Polymerase Chain Reaction

\section{Background}

The microbial population in the dental plaque is very complex. Development of human periodontitis is particularly related to the number of normal oral flora (1). From more than 500 different types of oral cavity isolated bacteria (2), only a small proportion has been documented as periodontal pathogens $(3,4)$. The major pathogenic bacteria species in etiology of periodontal diseases are Aggregatibacter actinomycetemcomitans (formerly Actinobacillus actinomycetemcomitans) and Porphyromonas gingivalis $(5,6)$. Prevotella intermedia, Tannerella forsythensis and Treponema denticola are some of the oral normal flora associated to periodontal disease (7).

An inflammatory disorder, involving the supporting structures of the teeth is defined as periodontitis. Unfortunately, periodontitis damages are permanent and may expand to such a degree that complex and prolonged therapy is essential to control the condition. With decrease the incidence of dental caries in adults, periodontitis has become the most common cause for tooth loss (8). The bacterial species mentioned above are frequently isolated from the damaged periodontal sites (9-11), and it has been suggested that bacterial collaboration might promote the infectious process of periodontal disease. Consequently, it is important to know the composition of microorganisms in human periodontal pockets for diagnosis and rational treatment. Accordingly, it is important to recognize the composition of bacteria in human periodontal pockets for diagnosis and disease management (12).

In addition to culture based methods, techniques such as immunoassays, enzyme assays, and nucleic acid probe assays have been developed for the identification of some oral pathogens (13-17). Nevertheless, detection limit of the techniques is about between 103 to 105 tar- 
gets per sample. Laboratory techniques have depth effect on detection of these putative pathogens in periodontal health and disease. Although classic method such as cultivation are used for oral microbial evaluations, but the microbial profile can be significantly underestimated because many bacteria (especially anaerobes) cannot be cultivated through these techniques. Also isolation and cultivation of the oral flora is accepted as the gold standard for many years (18).

Nowadays, polymerase chain reaction (PCR) is regarded as a vital tool for the rapid, sensitive, and specific detection of various bacterial and viral pathogens (19). Also real-time PCR has been proposed as a powerful diagnostic tool for rapid, sensitive and quantitative detection of the bacterial pathogens (20). Easy monitoring of periodontitis and more accurate epidemiological studies on the succession of periodontal disease are major consequents of developing an accurate non-culture based assay for detecting the oral pathogens (7).

\section{Objectives}

In this study, we designed and developed both PCR and SYBR Green real time PCR assays for immediate detection of A. actinomycetemcomitans and T. forsythensis then compared analytical sensitivity and specificity of the assays. Although several PCR-based methods for detection of the oral pathogens have been reported $(18,19,21-26)$, we hereby report the first designed duplex PCR and real time PCR assays in Iran for sensitive, specific and rapid detection of the two pathogens. To address an improved PCR assay po- tentially capable for application in clinic, recommendations of CLSI (Clinical Laboratory Standards Institute) for evaluation and validation of the molecular assays such as analytic sensitivity and analytic specificity were noted.

\section{Materials and Methods}

\subsection{The Bacterial Strains}

The genome of wild type bacteria of $A$. actinomycetemcomitans strain HK1651 (ATCC 700685D-5) and T. forsythensis strain FDC 338 (ATCC 43037D-5) were used as positive control. Negative control bacteria were bought in lyophilized form explained in Table 1 . The bacterial genomes were extracted using DNP ${ }^{\mathrm{TM}}$ kit (Cinnagen, Iran) then, the purity of culture was approved. The extracted genomes were quantified using a Picodrop Spectrophometer (Picodrop, UK) according to the manufacturer's instructions.

\subsection{Designing the Target Gene Primers}

Hemoglobin-binding protein (hbpA) gene of A. actinomycetemcomitans and $16 \mathrm{~S}$ rRNA gene of T. forsythensis were targeted for specific primer pair designing. All 83 NCBI deposited sequences of hbpA gene and 10 NCBI deposited sequences of $16 \mathrm{~S}$ rRNA gene were found, downloaded and aligned by CLC Main Workbench software version 5.5 (The accession numbers not shown). Allele ID software version 7.60 was used for designing primers based on the two alignment resulted consensus sequence. The characteristics of the designed primer pairs are described in Table 2.

\begin{tabular}{lll}
\hline \multicolumn{3}{l}{ Table 1. Specifications of the Negative Control Bacteria Used in the Study } \\
\hline Organism Name & Strain Number & \multicolumn{1}{c}{ Supplier } \\
\hline Staphylococcus aureus & ATCC 25923 & \\
Bacillus subtilis & ATCC 6051 & \\
\hline Shigella sonnei & ATCC 9290 & Pasture Institute of Iran \\
\hline Escherichia coli & ATCC 25922 & \\
\hline Enterococcus faecalis & ATCC 29212 & \\
\hline Pseudomonas aeruginosa & ATCC 27853 & \\
\hline Klebsiella pneumoniae & ATCC 7881 & \\
\hline Yersinia enterocolitica & PTCC 1480 & \\
\hline Yersinia pseudotuberculosis & PTCC 1244 & \\
\hline Proteus vulgaris & PTCC 1079 & \\
\hline Citrobacter freundii & PTC & \\
\hline
\end{tabular}

\subsection{Conventional PCR Experiment}

Two PCR experiments were conducted in a volume of $25 \mu \mathrm{L}$, consisting $1 \times$ PCR buffer (Fermentas, GmbH, Germany), $2 \mathrm{mM} \mathrm{Mg}^{2+}, 0.2 \mathrm{mM}$ dNTPs, $0.5 \mu \mathrm{M}$ of F-AggregahbpA, R- Aggrega-hbpA or F-Tan-16, R-Tan-16 primers pair (Table 2), $2 \mu \mathrm{L}$ of A. actinomycetemcomitans or T. forsythensis

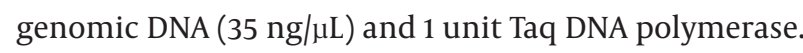
Amplification using a certain thermal program was carried out for 35 cycles in the PCR program was set as follow: initial denaturation at $95^{\circ} \mathrm{C}$ for 5 minutes, denaturation at $95^{\circ} \mathrm{C}$ for 1 minute, and annealing temperature at $60.8^{\circ} \mathrm{C}$ for 45 seconds and extension time at $72^{\circ} \mathrm{C}$ for 45 seconds. 
Soleimani M et al.

Table 2. Characteristics of the Designed Primer Pairs That Were Utilized for Molecular Detection of A. actinomycetemcomitans and T. forsythensis

\begin{tabular}{|c|c|c|c|c|}
\hline Bacterium & Target Gene & Primer Name & Primer Sequence & Product Length, bp \\
\hline \multirow{2}{*}{$\begin{array}{l}\text { Aggregatibacter actino- } \\
\text { mycetemcomitans }\end{array}$} & hbpA & F-Aggrega- hbpA & $5^{\prime}$ - AGACCCAATGCAAAAGTAACG & 160 \\
\hline & & R-Aggrega- hbpA & $5^{`}$ - GCAGTTCTGGGCTGAATTG & \\
\hline \multirow[t]{4}{*}{ Tannerella forsythensis } & $16 \mathrm{~S}$ rRNA & F-Tan-16 & $5^{\prime}$ - GCATGTACCTTGTGAATAAGCA & 250 \\
\hline & & R-Tan-16 & $5^{\prime}$ - CTTCGCAATCGGAGTTCTG & \\
\hline & $16 \mathrm{~S}$ rRNA & 16S-350F, Universal primer & $5^{\prime}$-CCTACGGGAGGCAGCAGT & 475 \\
\hline & & 16S-820R, Universal primers & $5^{`}$-CGTTTACGGCGTGGACTAC & \\
\hline
\end{tabular}

The annealing temperature optimization was done using gradient PCR ranged from 58 to $63^{\circ} \mathrm{C}$. In addition a 25 $\mu \mathrm{L}$ reaction was amplified with the same condition but distilled water was used instead of bacterial genomes as the negative control. In order to determine the presence of amplicons, the PCR products were separated by electrophoresis on $2 \%$ agarose gel containing ethidium bromide intercalating dye. To improve the assays for simultaneous detection of the genes, a duplex PCR assay was set up. With a volume of $50 \mu \mathrm{L}$, the duplex PCR assay consisted of $3 \mathrm{mM} \mathrm{Mg}{ }^{2+}, 2 \mathrm{mM}$ dNTPs, $0.2 \mu \mathrm{M}$ of the both primers pairs and 1 unit of Taq DNA polymerase enzyme.

\subsection{Development of Positive Control Sequences}

The positive control is used to ensure that the PCR has been done and determine the band length of target sequence. Accordingly, cloning of PCR products of hbpA and 16S rRNA genes in plasmid vector was used in present study. TA cloning was done by InsTA clone PCR cloning kit (Fermentas, Lithuania) according to the manufacturer's protocol. then the recombinant gene was transformed in to E. coli Top10 $\mathrm{F}^{-}$, colony-PCR was used for detecting the recombinant clones.Also digestion by BglII restriction enzyme (Fermentas, Lithuania) was used to confirm hbpA sequence received clones. This enzyme has one restriction site at nucleotide 56 located in hbpA gene. A similar experiment was done on clones receiving 16S rRNA sequence using restriction enzyme MboI (Fermentas, Lithuania). This enzyme has one restriction site at nucleotide 244 on 16S rRNA sequence. The confirmed recombinant plasmids named pTZ57R/T-hbpA and pTZ57R/T-16S, representing plasmids contained hbpA and $16 \mathrm{~S}$ rRNA genes respectively.

\subsection{SYBR Green Real Time PCR Experiment}

All reactions were performed using an ABI 7500 Fast Real-Time Amplification system (ABI, USA) and SYBR® Premix Ex Taq ${ }^{\mathrm{TM}}$ II (TAKARA, Japan). Real-time PCR was performed in a final volume of $20 \mu \mathrm{L}$ containing $2 \mu \mathrm{L}$ of A. actinomycetemcomitans or T. forsythensis genomic DNA (35 ng/ $\mu \mathrm{L}$ ) as template, $2 \mu \mathrm{L}$ of $2 \mathrm{X}$ master mix, 0.4 M each of the forward and reverse primers (Table 2). The thermal profile consisted of a 10 min of Taq polymerase activation at $95^{\circ} \mathrm{C}$ by 40 cycles of PCR (denaturation $95^{\circ} \mathrm{C} 15 \mathrm{sec}$, annealing and extension $\left.60^{\circ} \mathrm{C} 1 \mathrm{~min}\right)$. During the primer extension of each cycle, the increased amount of fluorescence from the amplified DNA was recorded by using the SYBR Green optic channel set at a wave length of 495 $\mathrm{nm}$. The initial threshold value was set to 0.22 fluorescent units. A negative control with PCR-grade water instead of template DNA was used in this test. Following amplification, to verify the correct product by its specific melting temperature (Tm), a melting curve analysis of the amplified DNA was performed at 54 to $95^{\circ} \mathrm{C}$, the temperature increasing rate of $0.2^{\circ} \mathrm{C} / \mathrm{sec}$ was considered in this test. Also the reaction products were held at $4-8^{\circ} \mathrm{C}$ until were subjected to further analyzes by electrophoresis in $2 \%$ agarose gel.

\subsection{Determination of Sensitivity and Limit of De- tection (LOD)}

To determine the reaction sensitivity or minimum copy number of the target genes that are able to show a visible bond in the PCR or a detectable signal in SYBR green real time PCR related melt curve analysis was measured. To this purpose, 10 -fold serial dilution of the pTZ57R/T-hbpA (1740 pg - $1.74 \mathrm{fg}$ ) and pTZ57R/T-16S (42 pg - $0.42 \mathrm{fg}$ ) was prepared. After performing triplicate PCR or SYBR green real time PCR with the mentioned dilutions, the last dilutions demonstrating amplification of the target genes were determined as the LOD of the corresponding assay. Finally, the DNA concentrations of the last dilutions were converted as the copy number of the respective gene (27). To develop the SYBR green real time PCR tests into quantitative assays and copy number determination of the hbpA and 16S rRNA genes, the standard curves were generated by plotting the Ct values against log DNA concentration and linear regression was calculated using the ABI 7500 Data Analysis software, version 2.0.1.

\subsection{Specificity Evaluation of the Assays}

To determine the specificity and investigate the probability of non-target genes replication in other microor- 
ganisms, the genome of control negative bacteria (Table 1) was studied by the designed assays. To ensure the presence of replicable DNA in the negative control bacterial genomes, the amplification of universal 16S rRNA gene was done and confirmed samples were used for experiments of characteristics determination (28). Table 2 shows universal primers used for this evaluation.

\section{Results}

PCR assay results related to the two chromosomal genes, were positive for both hbpA and 16S rRNA genes. The optimum annealing temperature for amplification of the genes was $60.8^{\circ} \mathrm{C}$. Amplified fragments of the hbpA and 16S rRNA with the lengths of 160 bp and 250 bp respectively were determined on the agarose gel. Gel agarose electrophoresis of the multiple assay products showed fast amplification of the both fragments (Figure 1). In SYBR Green real time PCR experiments, using the genes specific primers of A. actinomycetemcomitans or T. forsythensis, the related genomic DNA samples generated fluorescent signals. For the reactions using $100 \mathrm{ng}$ genomic DNA of A. actinomycetemcomitans , a Ct value of
13 was obtained.

Figure 1. Uniplex and Duplex PCR Amplification of the hbpA and 16S rRNA Genes

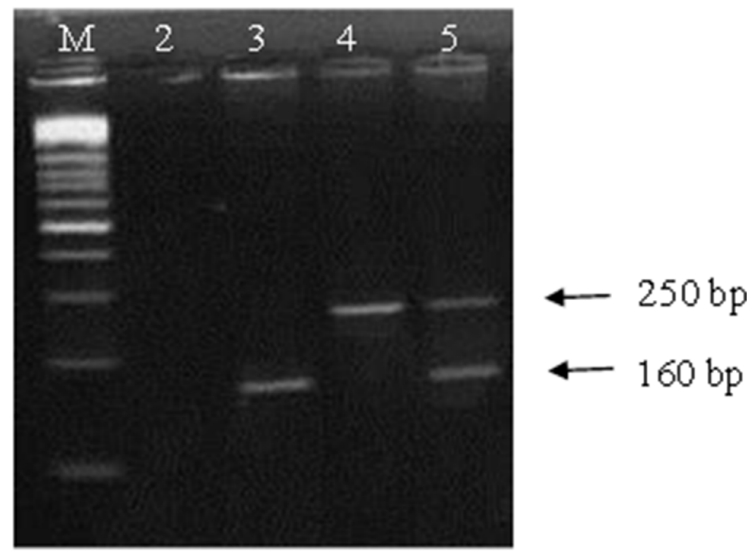

M, 100 bp DNA ladder; 2, negative control; 3, PCR product of hbpA gene 4, PCR product of $16 \mathrm{~S}$ rRNA gene; 5 , multiplex PCR products of both genes
A

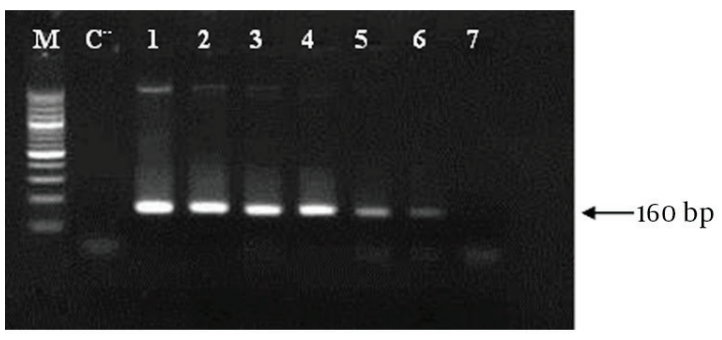

B

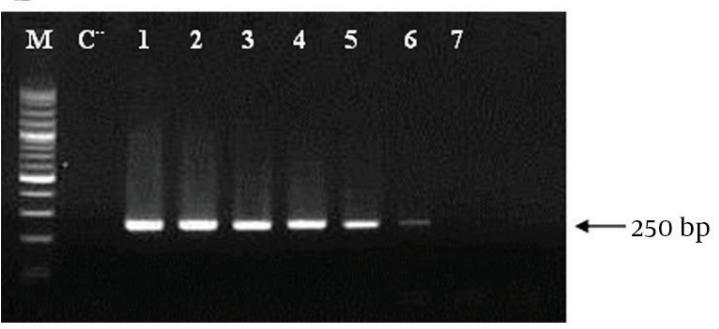

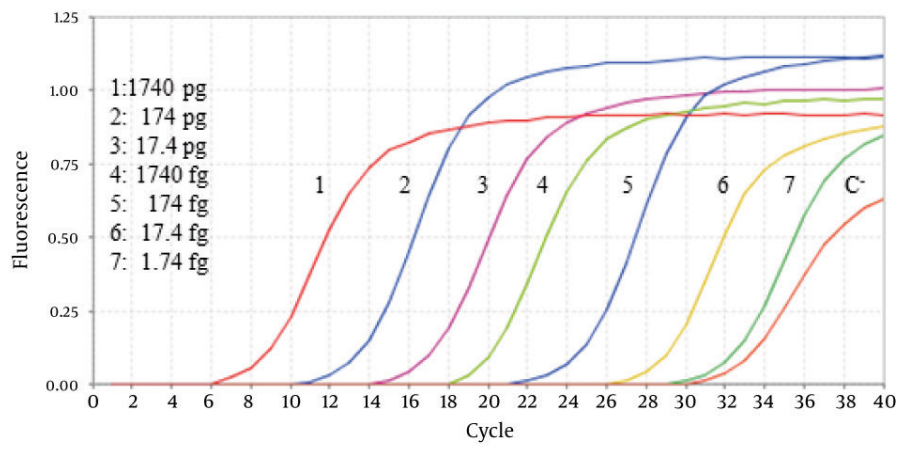

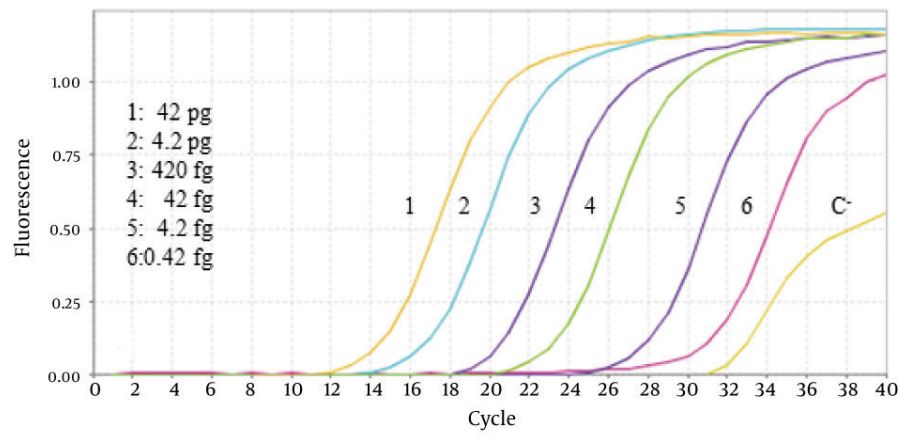

Figure 2. Melting Curve Analysis of Multiplex SYBR Green Real-Time Assay for Detection of A. actinomycetemcomitans (hbpA gene) and T. forsythensis (16S rRNA gene)

The Ct value of the reactions containing 100 ng genomic DNA of $T$. forsythensis was 12 . Temperature melting analyses of the assays showed the $\mathrm{Tm}$ at $78.02^{\circ} \mathrm{C}$ and $84.62^{\circ} \mathrm{C}$ for hbpA and $16 \mathrm{~S}$ rRNA genes respectively. Figure 2 shows the melting curve generated for detection of the genes using the ABI 7500 Fast real time amplification system. As expected agarose gel electrophoresis analysis of the products confirmed the amplification of the $160 \mathrm{bp}$ and 
250 bp bands (data not shown). No signal generation was seen in negative control tubes.

To prepare the sequences as positive controls, PCR products of hbpA and 16S rRNA genes were cloned in pTZ57R/T plasmid. Confirmation of the recombinant plasmids (pTZ57R/T-hbpA and pTZ57R/T-16S) conducted by PCR amplification of inserted sequences, and as expected, 160 and 250 bp bands on agarose gel were observed. Final confirmation of pTZ57R/T-hbpA plasmid by BglII restriction enzyme digestion resulted in a 3050 bp band on agarose gel. Also MboI restriction enzyme digestion of pTZ57R/T-16S plasmid resulted in a fragment with the length of $3136 \mathrm{bp}$ on agarose gel (data not shown).

The last dilution of pTZ57R/T-hbpA plasmid that resulted in a distinct 160 bp band on agarose gel after conventional PCR was $17.4 \mathrm{fg}$. The last dilution for pTZ57R/T-16S plasmid was $4.2 \mathrm{fg}$ (Figure 3, A1 and B1). Regarding the results, the lower detectable copy number for the hbpA and $16 \mathrm{~S}$ rRNA genes of a $25 \mu \mathrm{L}$ PCR reaction was considered as 5200 and 1200 copies respectively. After performing the SYBR Green real time PCR assays in triplicate on the 10- fold serial dilutions of pTZ57R/T-hbpA and pTZ57R/T-16S, the amplification curves confirmed the dilution increase and the standard curves were illustrated (Figure 3, A2 and B2). Comparing with the conventional PCR, the designed SYBR green PCR assays tenfold increased the test sensitivity. So the lower limit of detection of the assays for hbpA and 16S rRNA gene were $1.74 \mathrm{fg}$ (520 copies) and $0.42 \mathrm{fg}$ (120 copies) respectively.

The hbpA gene SYBR green assay was linear in the range of $1.74-1.74 \times 10^{6} \mathrm{pg}$ of pTZ57R/T-hbpA (520 - 520 $\times 10^{6}$ copies). The linearity for $16 \mathrm{~S}$ rRNA gene SYBR green assay was in the range of $0.42-42 \times 10^{6} \mathrm{pg}$ of pTZ57R/T-16S (120 $120 \times 10^{5}$ copies). The slope of -3.93 , Y-intercept of 37.709, R2 of 0.998 and amplification efficiency of $79.65 \%$ were the specifications of the regression line for the standard curve generated by the hbpA SYBR real time assay. The slope, Y-intercept, R2 and amplification efficiency of the regression line for the standard curve generated by the 16S rRNA SYBR real time assay was -33.63, 29.602, 0.986 and $98.326 \%$ respectively (Figure 4 ).

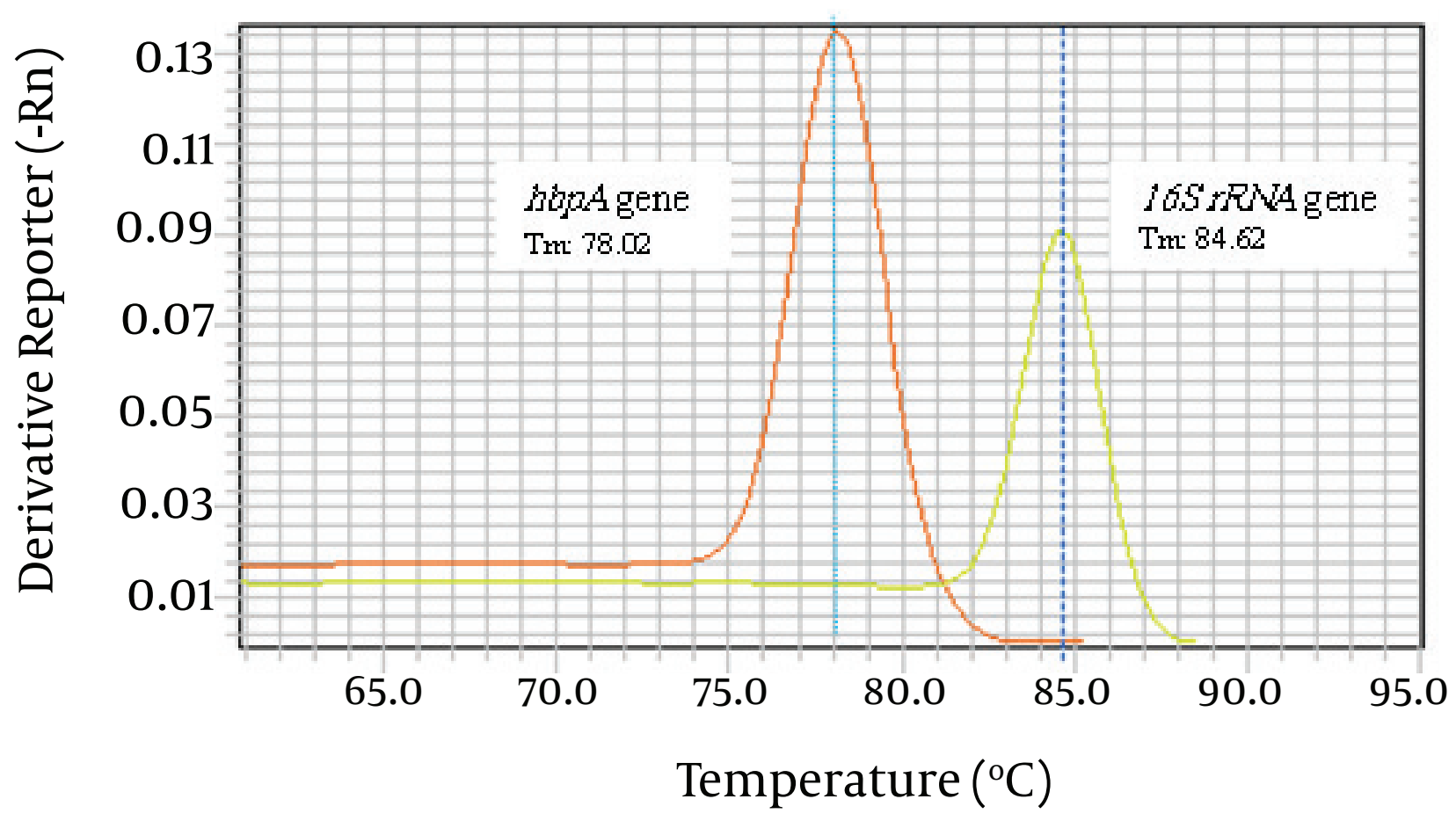

Figure 3. The Sensitivity Comparison of the Conventional and SYBR Green PCR Assay for Detection of A. actinomycetemcomitans and T. forsythensis.

Conventional or SYBR real time PCR of both hbpA and $16 \mathrm{~S}$ rRNA genes on genome of the negative control bacteria (Table 1) did not resulted to any band on agarose gel or fluorescent signal in the ABI 7500 Fast real time amplification system indicating the characteristics of both assays (data not shown). The PCR amplification of 16S rRNA universal gene on the genome of negative control bacteria resulted in a 475 bp band on agarose gel which indicated the presence of replicable fragment and the absence of PCR inhibitor (data not shown). 

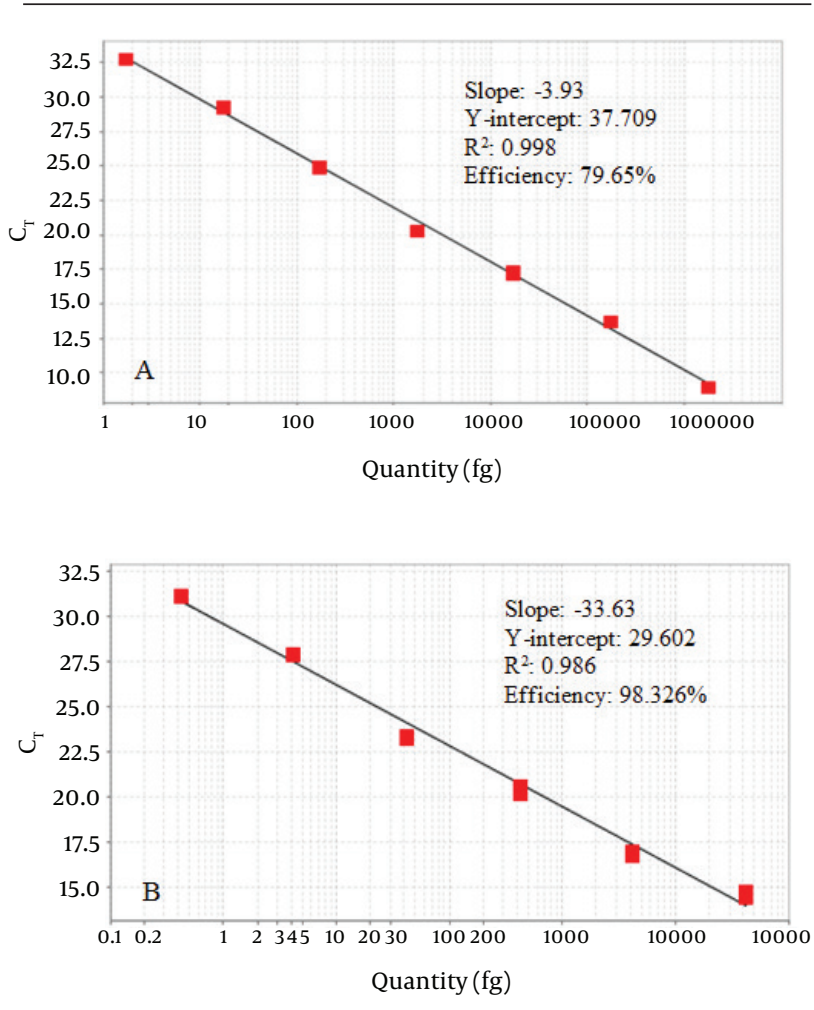

Figure 4. Standard Curve Analyses and the Linearity Range of the SYBR Green Real Time PCR for Quantitative Detection of hbpA Gene of A. actinomycetemcomitans (A) and 16S rRNA Gene of T. forsythensis (B)

\section{Discussion}

Various studies in recent years have shown that oral diseases, such as periodontal diseases, are the risk factors or indicators for some systemic diseases such as coronary disease, stroke, peripheral vascular diseases, metabolic syndromes, hypertension, obesity and hyperlipidemia (29). Recently, it has been proposed that periodontal disease may be associated with breast cancer (30). Oral microbiologic profile determination could be a suitable approach for management of the oral diseases. Classical tests based on traditional phenotypic methods are very time consuming and inconvenient and on the other hand sometimes diagnosis and isolation of these bacteria are not easily done. In contrast, PCR as a steadfast, precise and sensitive method can be reasonable and suitable advanced replacement for diagnosis and control of these bacteria $(7,31)$.

In this study to achieve simple, rapid and accurate methods for detecting two of the most important bacteria in oral diseases, we designed and compared two diagnostic molecular assays. So a multiplex PCR assay and a quantitative SYBR green real time PCR for simultaneous detection of A. actinomycetemcomitans and T. forsythensis were designed and their analytical specificity and sensitivity was evaluated. One of the most important points in this approach is the primers design. After downloading sequences of the target genes from GeneBank of NCBI, they were aligned and then the consensus region was used for designing primers. It guarantees that the diagnostic primers anneal to all versions of the genes that are currently registered in GeneBank . It's notable that in most of the studies, just one sequence has been used for primer design.

Multiplex PCR method is a suitable, precise and sensitive method due to reducing detection time with the basis of targeting different diagnostic genes of causative microorganisms . An additional important subject for designing multiplex primers is their Tm values which must be similar whereas the PCR products have different sizes. In this study compared with other similar studies, all the mentioned points were investigated. In a study by Leblebicioglu et al. in 2009, the PCR products were not differentiable and the band sizes were too short but the present study was designed in a way that the band sizes are at least $100 \mathrm{bp}$ (32).

In this study, the PCR products were cloned into pTZ57R/T plasmid after optimized amplification of the target genes, and also to practice in following steps of the study the confirmed plasmids were used as positive controls. In nearly all other studies, the genomic DNA has been used as the positive control, Leblebicioglu et.al studies, in 2009 are the examples in this regard (32). It is obvious that cloning a gene into a plasmid vector in addition to inestimable access to the desired amount of amplified gene is possible to take advantage of having a stable positive control through cloning the gene into the plasmid.

The high sensitivity of the designed conventional PCR assay was determined via LOD determination. As a result, the LOD was 1200 copies for 16S rRNA gene and 5200 copies for hbpA gene. D'Ercole et al., in 2008 have compared the culture method and $16 \mathrm{~S}$ rRNA gene multiplex PCR to detect the periodont pathogenic bacteria. The LOD of their multiplex PCR was $10^{2}-10^{3}$ cells (33). Flemmig et al.in 1995, by used the artificial contamination method to calculate the LOD of leukotoxin gene lktA to detect A. actinomycetemcomitans finding $10^{3} \mathrm{CFU} / \mathrm{mL}$. In their study, enriching the samples on tryptic soy-serum-bacitracin-vancomycin agar prior to PCR improved the LOD to $10^{2} \mathrm{CFU} / \mathrm{mL}$ (34). Conrads and his colleagues in 1999 determined the LOD of 16S rRNA PCR to detect T. forsythensis as $50 \mathrm{CFU} / \mathrm{mL}$ (35). The variation in the LOD estimations is partially due to the use of different primers and/or performing PCR using various thermal cycling programs. Also the selected methods for the estimation can influence the final results. LOD is one of the most important items in target amplification tests and there are various methods for its determination.

According the above studies one of these methods is preparing serial dilution of bacteria, counting and determining the CFU. Despite the high accuracy of these techniques, being time consuming and necessity to use live bacteria are some of its disadvantages. The other method to determine LOD is to measure the genome concentration, prepare serial dilution, estimate genome copy number in each dilution, conducting PCR at different dilutions, and finally estimate the LOD. However, one of the important disadvantages of this method is its low 
precision. According to various studies, cloning of target gene in plasmid and then preparing serial dilutions from it and PCR is one of the best methods for LOD determination (36) which was also used in the present study.

To improve the sensitivity or LOD of the conventional PCR assay and obtain a quantitative assay, we tried the same primers in SYBR green real time PCR approach. Fortunately, the hbpA-16S rRNA SYBR green PCR assays at least tenfold increased the test sensitivity. Most of the oral pathogens are present in normal oral cavity with a low profile, but in periodontal diseases increase in their numbers can be happened. So a quantitative molecular method can play a critical role in evaluation of the health or disease of the oral cavity. Although quantitative anaerobic culture is a gold standard for number estimation of the oral pathogens, time consuming, laboring and relatively low level of sensitivity are some of its difficulties.

Various studies have shown a high concordance between results of anaerobic culture and real time PCR method in microbiological evaluation of periodontitis cases $(25,37-39)$. In our quantitative real time PCR experiments, the generated standard curves showed a linear range of $1.74-1.74 \times 10^{6} \mathrm{pg}\left(520-520 \times 10^{6}\right.$ copies $)$ and 0.42 - $42 \times 10^{6} \mathrm{pg}\left(120-120 \times 10^{5}\right.$ copies $)$ for pTZ57R/T-hbpA and pTZ57R/T-16S templates respectively. So to quantify unknown samples in the above ranges, the $\mathrm{Ct}$ value can be used on the standard curves of the respect target gene. to prove the claim, evaluation of the designed assays by using sample plaques of patients or artificially contaminated dental plaques is necessary.

The periodontopathogenic bacteria play an important role in the development and progress of the oral diseases. Thus, diagnosis of $A$. actinomycetemcomitans and T. forsythensis by using multiplex conventional and SYBR green real time PCR will supply necessary information about the oral bacterial profile and predicting disease in adult periodontitis. This study is the first report of developing and comparing conventional and real time multiplex PCR assay for the oral pathogens in Iran by designing primers and determining sensitivity and specificity, all the criteria necessary for a molecular diagnostic method are met. Domestication and design of the assays in Iran is an important step towards flourishing and development of medical diagnostic laboratories techniques for accurate and precise diagnosis of the oral pathogens.

\section{Acknowledgments:}

This study was conducted with contributions of the members of the Research Council of the Islamic Azad University Qom branch and the staff of microbiology laboratory are also sincerely appreciated.

\section{Authors' Contribution}

This study was conducted with contributions of the members of the Research Council of the Islamic Azad
University Qom branch and the staff of microbiology laboratory are also sincerely appreciated.

\section{Financial Disclosure}

There is no Financial Disclosure.

\section{Funding/Support}

This study was conducted with financial support provided by the Islamic Azad University Qom branch.

\section{References}

1. Psoter WJ, Ge Y, Russell SL, Chen Z, Katz RV, Jean-Charles G, et al. PCR detection of Streptococcus mutans and Aggregatibacter actinomycetemcomitans in dental plaque samples from Haitian adolescents. Clin Oral Investig. 2011;15(4):461-9.

2. Paster BJ, Boches SK, Galvin JL, Ericson RE, Lau CN, Levanos VA, et al. Bacterial diversity in human subgingival plaque. J Bacteriol. 2001;183(12):3770-83.

3. Socransky SS, Haffajee AD, Ximenez-Fyvie LA, Feres M, Mager D. Ecological considerations in the treatment of Actinobacillus actinomycetemcomitans and Porphyromonas gingivalis periodontal infections. Periodontol 2000.1999;20:341-62.

4. Kumar PS, Griffen AL, Moeschberger ML, Leys EJ. Identification of candidate periodontal pathogens and beneficial species by quantitative 16 S clonal analysis. J Clin Microbiol. 2005;43(8):394455.

5. Slots J, Ting M. Actinobacillus actinomycetemcomitans and Porphyromonas gingivalis in human periodontal disease: occurrence and treatment. Periodontol 2000.1999;20:82-121.

6. Kozarov EV, Dorn BR, Shelburne CE, Dunn WA, Jr, Progulske-Fox A. Human atherosclerotic plaque contains viable invasive Actinobacillus actinomycetemcomitans and Porphyromonas gingivalis. Arterioscler Thromb Vasc Biol. 2005;25(3):e17-8.

7. Nonnenmacher C, Dalpke A, Mutters R, Heeg K. Quantitative detection of periodontopathogens by real-time PCR.J Microbiol Methods. 2004;59(1):117-25.

8. Shelburne CE, Prabhu A, Gleason RM, Mullally BH, Coulter WA. Quantitation of Bacteroides forsythus in subgingival plaque comparison of immunoassay and quantitative polymerase chain reaction.J Microbiol Methods. 2000;39(2):97-107.

9. Simonson LG, McMahon KT, Childers DW, Morton HE. Bacterial synergy of Treponema denticola and Porphyromonas gingivalis in a multinational population. Oral Microbiol Immunol. 1992;7(2):111-2.

10. Socransky SS, Haffajee AD, Dzink JL, Hillman JD. Associations between microbial species in subgingival plaque samples. Oral Microbiol Immunol. 1988;3(1):1-7.

11. Hashimoto M, Ogawa S, Asai Y, Takai Y, Ogawa T. Binding of Porphyromonas gingivalis fimbriae to Treponema denticola dentilisin. FEMS Microbiol Lett. 2003;226(2):267-71.

12. Suzuki N, Yoshida A, Saito T, Kawada M, Nakano Y. Quantitative microbiological study of subgingival plaque by real-time PCR shows correlation between levels of Tannerella forsythensis and Fusobacterium spp.J Clin Microbiol. 2004;42(5):2255-7.

13. Slots J. Rapid identification of important periodontal microorganisms by cultivation. Oral Microbiol Immunol. 1986;1(1):48-57.

14. Bonta Y, Zambon JJ, Genco RJ, Neiders ME. Rapid identification of periodontal pathogens in subgingival plaque: comparison of indirect immunofluorescence microscopy with bacterial culture for detection of Actinobacillus actinomycetemcomitans. J Dent Res. 1985;64(5):793-8.

15. Savitt ED, Strzempko MN, Vaccaro KK, Peros WJ, French CK. Comparison of cultural methods and DNA probe analyses for the detection of Actinobacillus actinomycetemcomitans, Bacteroides gingivalis, and Bacteroides intermedius in subgingival plaque 
samples. J Periodontol.1988;59(7):431-8.

16. Alsina M, Olle E, Frias J. Improved, low-cost selective culture medium for Actinobacillus actinomycetemcomitans. J Clin Microbiol. 2001;39(2):509-13.

17. Ramseier CA, Kinney JS, Herr AE, Braun T, Sugai JV, Shelburne CA, et al. Identification of pathogen and host-response markers correlated with periodontal disease. J Periodontol. 2009;80(3):436 46.

18. Boutaga K, van Winkelhoff AJ, Vandenbroucke-Grauls CM, Savelkoul PH. The additional value of real-time PCR in the quantitative detection of periodontal pathogens. J Clin Periodontol. 2006;33(6):427-33.

19. Yoshida A, Suzuki N, Nakano Y, Oho T, Kawada M, Koga T. Development of a 5' fluorogenic nuclease-based real-time PCR assay for quantitative detection of Actinobacillus actinomycetemcomitans and Porphyromonas gingivalis. J Clin Microbiol. 2003;41(2):863-6.

20. Boutaga K, van Winkelhoff AJ, Vandenbroucke-Grauls CM, Savelkoul PH. Comparison of real-time PCR and culture for detection of Porphyromonas gingivalis in subgingival plaque samples. J Clin Microbiol. 2003;41(11):4950-4.

21. Amano A, Kuboniwa M, Nakagawa I, Akiyama S, Morisaki I, Hamada S. Prevalence of specific genotypes of Porphyromonas gingivalis fimA and periodontal health status. J Dent Res. 2000;79(9):1664-8.

22. Ashimoto A, Chen C, Bakker I, Slots J. Polymerase chain reaction detection of 8 putative periodontal pathogens in subgingival plaque of gingivitis and advanced periodontitis lesions. Oral $\mathrm{Mi}$ crobiol Immunol.1996;11(4):266-73.

23. Oho T, Yamashita Y, Shimazaki Y, Kushiyama M, Koga T. Simple and rapid detection of Streptococcus mutans and Streptococcus sobrinus in human saliva by polymerase chain reaction. Oral Microbiol Immunol. 2000;15(4):258-62.

24. Suzuki N, Nakano Y, Yoshida Y, Ikeda D, Koga T. Identification of Actinobacillus actinomycetemcomitans serotypes by multiplex PCR. JClin Microbiol. 2001;39(5):2002-5.

25. Boutaga K, van Winkelhoff AJ, Vandenbroucke-Grauls CM, Savelkoul PH. Periodontal pathogens: a quantitative comparison of anaerobic culture and real-time PCR. FEMS Immunol Med Microbiol. 2005;45(2):191-9.

26. Orru G, Marini MF, Ciusa ML, Isola D, Cotti M, Baldoni M, et al Usefulness of real time PCR for the differentiation and quantification of 652 and JP2 Actinobacillus actinomycetemcomitans genotypes in dental plaque and saliva. BMC Infect Dis. 2006;6:98.

27. Sambrook J, Russell DW. Molecular Cloning: A Laboratory Manual.:
Cold Spring Harbor Laboratory Press; 2001.

28. Chiang YC, Yang CY, Li C, Ho YC, Lin CK, Tsen HY. Identification of Bacillus spp., Escherichia coli, Salmonella spp., Staphylococcus spp. and Vibrio spp. with $16 \mathrm{~S}$ ribosomal DNA-based oligonucleotide array hybridization. Int J Food Microbiol. 2006;107(2):131-7.

29. Dumitrescu AL. Etiology and Pathogenesis of Periodontal Disease.: Springer; 2010.

30. Soder B, Yakob M, Meurman JH, Andersson LC, Klinge B, Soder PO Periodontal disease may associate with breast cancer. Breast Cancer Res Treat. 2011;127(2):497-502.

31. Tonjum T, Haas R. Identification of Actinobacillus actinomycetemcomitans by leukotoxin gene-specific hybridization and polymerase chain reaction assays. J Clin Microbiol.1993;31(7):1856-9.

32. Leblebicioglu B, Kulekci G, Ciftci S, Keskin F, Badur S. Salivary detection of periodontopathic bacteria and periodontal health status in dental students. Anaerobe. 2009;15(3):82-6.

33. D'Ercole S, Catamo G, Tripodi D, Piccolomini R. Comparison of culture methods and multiplex PCR for the detection of periodontopathogenic bacteria in biofilm associated with severe forms of periodontitis. New Microbiol. 2008;31(3):383-91.

34. Flemmig TF, Rudiger S, Hofmann U, Schmidt H, Plaschke B, Stratz A, et al. Identification of Actinobacillus actinomycetemcomitans in subgingival plaque by PCR. J Clin Microbiol. 1995;33(12):3102-5.

35. Conrads G, Flemmig TF, Seyfarth I, Lampert F, Lutticken R. Simultaneous detection of Bacteroides forsythus and Prevotella intermedia by 165 rRNA gene-directed multiplex PCR. J Clin Microbiol. 1999;37(5):1621-4.

36. Soleimani M, Eini F, Fallah Raufi M, Azari F, Farzampour S Jamshidian E, et al. Design of Multiplex Polymerase Chain Reaction(PCR) Method for Molecular Detection of Yersinia pestis Bacterium. Yakhteh. 2010;12(3):363-370.

37. van Steenbergen TJ, Timmerman MF, Mikx FH, de Quincey G, van der Weijden GA, van der Velden U, et al. Discrepancy between culture and DNA probe analysis for the detection of periodontal bacteria.J Clin Periodontol.1996;23(10):955-9.

38. Slots J, Chen C. Detection of Porphyromonas gingivalis associated with human periodontitis by DNA methods. Clin Infect Dis. 1993;16 Suppl 4:S317-8.

39. Riggio MP, Macfarlane TW, Mackenzie D, Lennon A, Smith AJ Kinane D. Comparison of polymerase chain reaction and culture methods for detection of Actinobacillus actinomycetemcomitans and Porphyromonas gingivalis in subgingival plaque samples. J Periodontal Res. 1996;31(7):496-501. 